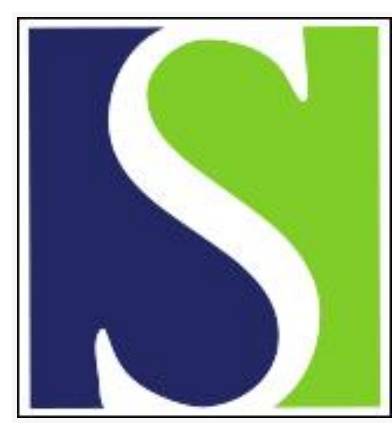

Scand J Work Environ Health 1988;14(3):175-180

https://doi.org/10.5271/sjweh.1934

Issue date: Jun 1988

Thyroid function as assessed by routine laboratory tests of workers with long-term lead exposure.

by Tuppurainen M, Wagar G, Kurppa K, Sakari W, Wambugu A, Froseth B, Alho J, Nykyri E

Affiliation: Institute of Occupational Health, Helsinki, Finland.

This article in PubMed: www.ncbi.nlm.nih.gov/pubmed/3393853

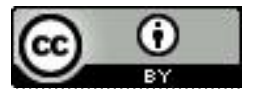




\title{
Thyroid function as assessed by routine laboratory tests of workers with long-term lead exposure
}

\author{
by Matti Tuppurainen, MD, ${ }^{1}$ Gustav Wägar, MD, ${ }^{2}$ Kari Kurppa, MD, ${ }^{1}$ William Sakari, MD, ${ }^{3}$ \\ Alexander Wambugu, MD, ${ }^{3}$ Bertil Fröseth, BSc, ${ }^{2}$ Juha Alho, PhD,$^{1}$ Erkki Nykyri, LSc ${ }^{1}$
}

\begin{abstract}
TUPPURAINEN M, WÄGAR G, KURPPA K, SAKARI W, WAMBUGU A, FRÖSETH B, ALHO J, NYKYRI E. Thyroid function as assessed by routine laboratory tests of workers with long-term lead exposure. Scand J Work Environ Health 14 (1988) 175-180. Thyroid function was studied in 176 male workers occupationally exposed to lead. The mean blood lead concentration of the workers was 2.70 (SD 1.15 , range $0.70-6.45) \mu \mathrm{mol} / 1$. The mean duration of lead exposure was 7.6 (range $0.1-20$ ) years. The total thyroxine (T4), free thyroxine (FT4), total triiodothyronine (T3), and thyrotropin concentrations in serum were similar in the workers in the low and high blood lead categories. In regression equations the duration of lead exposure had a weak but significant negative association with T4 and FT4, and this association was particularly pronounced when the analyses were restricted to workers with the most intense lead exposure over time. Thus, the results suggest that thyroid function might be depressed as a result of intense long-term lead exposure.
\end{abstract}

Key terms: duration of exposure, hypothyroidism, occupational.

Lead is the most ubiquitous nonferrous metal used in industry, and it is a suggested cause of hypothyroidism $(7,9)$. Decreased iodine intake by the thyroid gland has been reported in patients with lead poisoning (12). In a recent study, free thyroxine in serum correlated negatively to lead exposure in a group of workers of African origin (11). Such an effect was not seen in Caucasian workers, however. Some evidence based on tests of the stimulation of thyrotropin-releasing hormone indicate that lead causes a central depression of the pituitary-thyroid axis in man $(3,11)$. Refowitz (10) recently reported a study which did not show any significant relationship between thyroid function and the blood lead $(\mathrm{PbB})$ concentration of exposed workers.

This communication reports the results of a study on the effects of long-term lead exposure on thyroid function in a group of workers exposed in Kenyan lead industries. The results suggest that thyroid function might be depressed as a result of intense long-term lead exposure.

\section{Subjects and methods}

\section{Subjects}

The study group was formed of 202 African male workers in two Kenyan car battery factories and one secondary lead smeltery. Twenty-six (13\%) of the workers were either on leave when the serum samples

\footnotetext{
I Institute of Occupational Health, Helsinki, Finland.

2 Mjölbolsta Hospital, Mjölbolsta, Finland.

${ }^{3}$ Factories Inspectorate, Nairobi, Kenya.
}

Reprint requests to: Dr M Tuppurainen, Institute of Occupational Health, Topeliuksenkatu $4 \mathrm{I}$ a A, 00250 Helsinki, Finland. for thyroid indices were collected or declined to participate in the investigation. The age of the $176 \mathrm{ex}-$ amined workers ranged from 21 to 54 (mean 34.1) years. They had been occupationally exposed to lead for an average of 7.6 years, the periods of exposure ranging from a few months to 20 years (table 1 ).

\section{Blood and serum samples}

The blood and serum samples were taken in 1984 in a mobile clinic between 0800 and 1800 . First the subject's skin was disinfected with Neo-Amisept ${ }^{\circledR}$ (Farmos Corporation, Turku, Finland); then blood was drawn into heparinized lead-free test tubes. Three serum samples $(10 \mathrm{ml}$ each) were taken before the $\mathrm{PbB}$ sample in an effort to avoid lead contamination. The samples were frozen to $-20^{\circ} \mathrm{C}$ and kept in dry ice during transportation.

\section{Blood lead assay}

The exposure to lead was evaluated from determinations of the $\mathrm{PbB}$ concentration, which was measured

Table 1. Age and lead exposure variables of the workers $(\mathrm{N}=176) .(\mathrm{PbB}=$ blood lead, $\mathrm{EPP}=$ erythrocyte protoporphyrin)

\begin{tabular}{lccc}
\hline Variable & Mean & SD & Range \\
\hline $\begin{array}{l}\text { Age (years) } \\
\text { Duration of exposure }\end{array}$ & 34.1 & 8.1 & $21-54$ \\
$\begin{array}{l}\text { (years) } \\
\begin{array}{l}\text { PbB concentration } \\
\text { ( } \mu \text { mol/l) }\end{array}\end{array}$ & 7.6 & 5.1 & $0.1-20$ \\
$\begin{array}{l}\text { Individual average } \\
\begin{array}{l}\text { PbB concentration } \\
(\mu \mathrm{mol} / \mathrm{l})\end{array}\end{array}$ & 2.70 & 1.15 & $0.70-6.45$ \\
$\begin{array}{l}\text { EPP concentration } \\
(\mu \mathrm{mol} / \mathrm{l})\end{array}$ & 2.73 & 1.00 & $1.01-6.47$ \\
\hline
\end{tabular}


by electrothermal atomic absorption spectrophotometry (14) at the Institute of Occupational Health in Helsinki.

The analyses were performed on a polarized Zeeman atomic absorption spectrophotometer (Hitachi, model 7000) equipped with a graphite furnace, an automatic sampling system, and a data processor. The blood was diluted tenfold with an aqueous solution of diammonium hydrogen phosphate and Triton- $X-100^{\circledR}$. An aliquot of $20 \mu \mathrm{l}$ was injected into a graphite cup cuvette. The lead values were obtained from direct comparisons with matrix-matched working curves on the data processor.

The within-run precision (coefficient of variation) of this method, calculated from 10 consecutive measurements in a run, was $0.7 \%$ at a mean concentration of $0.7 \mu \mathrm{mol} / \mathrm{l}$ and $1.5 \%$ at a mean concentration of $3.4 \mu \mathrm{mol} / 1$. The day-to-day precision (coefficient of variation), calculated on the basis of 10 determinations from human blood during two weeks, was $2.8 \%$ at a concentration level of $2.09 \mu \mathrm{mol} / 1$. The accuracy of this method in the laboratory is controlled daily by the Behring Institute with measurements of two concentration levels of control blood specimens.

\section{Individual average blood lead concentration}

The cross-sectional $\mathrm{PbB}$ concentration reflects the intensity of relatively recent exposure. Most of the workers, however, had been exposed to lead for years. Therefore, for each worker, we also calculated a variable that was taken as a proxy for the typical intensity of past lead exposure by averaging the $\mathrm{PbB}$ concentrations measured in periodic medical examinations over the years. The $\mathrm{PbB}$ level of the workers had been followed between 1978 and 1984 by determinations performed by the National Occupational Hygiene Services Ltd, Manchester, England. The average PbB level in these measurements (with generally five $\mathrm{PbB}$ measurements available for each worker) was 2.73 (range $1.01-6.47$ ) $\mu \mathrm{mol} / 1$. The average $\mathrm{PbB}$ concentration was used as an explanatory variable in some of the statistical analyses.

\section{Erythrocyte protoporphyrin concentration}

The zinc protoporphyrin concentrations were measured from a drop of blood with an Environmental Science Associates hematofluorometer calibrated to determine total erythrocyte protoporphyrin (EPP) in whole blood (4).

The reliability of the instrument was daily controlled with three checker slides of fluorescent material. The coefficient of variation calculated from three parallel measurements was $5 \%$ at the concentration level of $0.5 \mu \mathrm{mol} / 1$ and $3 \%$ at the concentration level of 1.2 $\mu \mathrm{mol} / \mathrm{l}$.

\section{Thyroid function}

The thyroid function was assessed with commercial routine tests for the serum concentrations of the following hormones: total thyroxine (T4) by radioimmunoassay (Amerlex ${ }^{\circledR}$, Amersham International, Amersham, United Kingdom), free thyroxine (FT4) (Amerlex ${ }^{\circledR}$, Amersham, UK), and total triiodothyronine (T3) (Amerlex ${ }^{(B)}$, Amersham, UK). Thyroidstimulating hormone (TSH), ie, thyrotropin, was measured in serum by the radioimmunoassay method (Phadebas $^{\circledR}$, Pharmacia Diagnostics, Uppsala, Sweden).

\section{Statistical methods}

The statistical comparisons were made by Student's two-sided t-test and an analysis of variance. The relations between the thyroid hormones and the $\mathrm{PbB}$ concentration, the individual average $\mathrm{PbB}$ concentration, the EPP level, age, and the duration of exposure were studied with the use of multiple linear regression methods (1). Standard collinearity diagnostics were performed according to Weisberg (16).

\section{Results}

The mean $\mathrm{PbB}$ value of 2.70 (SD 1.15, range $0.70-$ 6.45) $\mu \mathrm{mol} / \mathrm{l}$ for the cohort in 1984 was used as a cutoff point between less intense and more intense exposure. Table 2 shows that the thyroid indices were similar in both of the PbB categories.

Figure 1 shows FT4 in serum as a function of the $\mathrm{PbB}$ concentration. Visual scrutiny of the scatter plot does not reveal any clear relationship between FT4 and $\mathrm{PbB}$, and the correlation ( $\mathrm{r}$ ) of these two factors was negligible $(\mathrm{N}=176, \mathrm{r}=0.026)$.

Table 3 gives the correlations of measures of thyroid function with the age and lead exposure variables.

Table 2. Means and standard deviations of the measures of thyroid function by the categories of blood lead (PbB) concentration. (T4 = total thyroxine, FT4 = free thyroxine, T3= triiodothyronine, TSH $=$ thyroid-stimulating hormone, ie, thyrotropin)

\begin{tabular}{|c|c|c|c|c|c|c|}
\hline \multirow{2}{*}{$\begin{array}{l}\text { Measure of } \\
\text { thyroid } \\
\text { function }\end{array}$} & \multicolumn{2}{|c|}{$\begin{array}{l}\text { All exposed } \\
(N=176)\end{array}$} & \multicolumn{2}{|c|}{$\begin{array}{c}\mathrm{PbB} \leq 2.70 \mu \mathrm{mol} / \mathrm{l} \\
(\mathrm{N}=93)\end{array}$} & \multicolumn{2}{|c|}{$\begin{array}{c}\mathrm{PbB}>2.70 \mu \mathrm{mol} / \mathrm{l} \\
(\mathrm{N}=83)\end{array}$} \\
\hline & Mean & SD & Mean & SD & Mean & $\mathrm{SD}$ \\
\hline $\begin{array}{l}\text { Serum T4 concentration ( } \mathrm{nmol} / \mathrm{l}) \\
\text { Serum FT4 concentration (pmol/I) } \\
\text { Serum T3 concentration ( } \mathrm{nmol} / \mathrm{l}) \\
\text { Serum TSH concentration }(\mathrm{mU} / \mathrm{l})\end{array}$ & $\begin{array}{r}99.9 \\
26.6 \\
1.9 \\
2.7\end{array}$ & $\begin{array}{r}18.9 \\
6.6 \\
0.4 \\
1.7\end{array}$ & $\begin{array}{r}99.2 \\
27.1 \\
1.9 \\
2.6\end{array}$ & $\begin{array}{r}19.0 \\
7.4 \\
0.4 \\
1.6\end{array}$ & $\begin{array}{r}100.8 \\
26.1 \\
1.9 \\
2.8\end{array}$ & $\begin{array}{r}18.9 \\
5.6 \\
0.4 \\
1.9\end{array}$ \\
\hline
\end{tabular}


FT 4

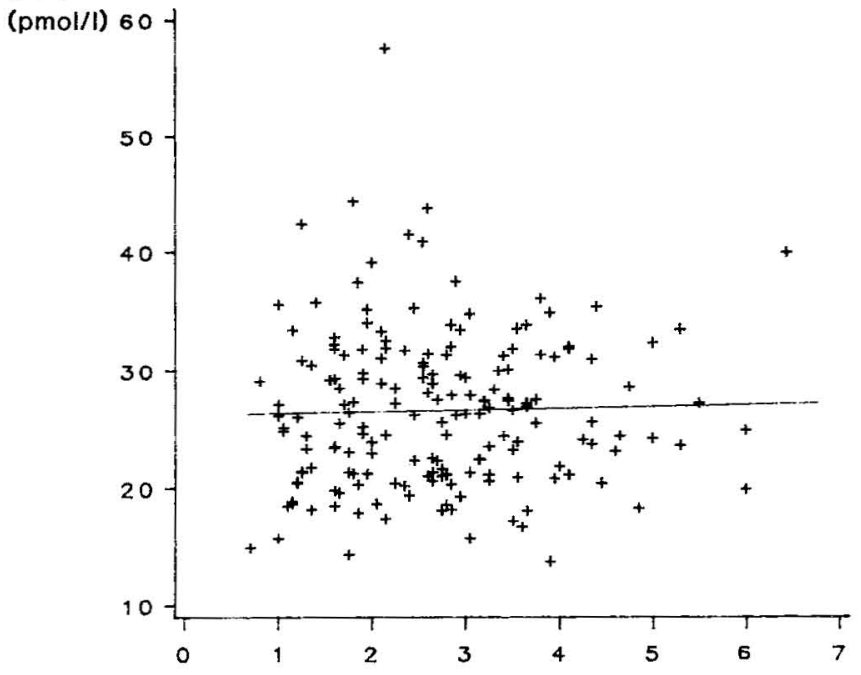

$\mathrm{Pb} \mid \mathrm{B}$

Figure 1. Relationship between the free thyroxine (FT4) concentration in serum and the blood lead concentration $(\mathrm{PbB})(\mathrm{N}=176$, $(\mu \mathrm{mol} / \mathrm{l}) \mathrm{r}=0.026)$.

Table 3. Correlation between the measures of thyroid function and age, the blood lead $(\mathrm{PbB})$ concentration, the erythrocyte protoporphyrin (EPP) concentration, the individual average $\mathrm{PbB}$ concentration, and the duration of exposure of the workers $(\mathrm{N}=176)$. ( $\mathrm{T} 4=$ total thyroxine, $\mathrm{FT} 4=$ free thyroxine, $\mathrm{T} 3=$ triiodothyronine, $\mathrm{TSH}=$ thyroid-stimulating hormone, ie, thyrotropin)

\begin{tabular}{|c|c|c|c|c|c|}
\hline $\begin{array}{l}\text { Measure of } \\
\text { thyroid } \\
\text { function }\end{array}$ & $\begin{array}{c}\text { Age } \\
\text { (years) }\end{array}$ & $\begin{array}{c}\mathrm{PbB} \\
\text { concentration } \\
(\mu \mathrm{mol} / \mathrm{l})\end{array}$ & $\begin{array}{c}\text { EPP } \\
\text { concentration } \\
(\mu \mathrm{mol} / \mathrm{l})\end{array}$ & $\begin{array}{c}\text { Individual } \\
\text { average PbB } \\
\text { concentration } \\
(\mu \mathrm{mol} / 1)\end{array}$ & $\begin{array}{c}\text { Duration of } \\
\text { exposure } \\
\text { (years) }\end{array}$ \\
\hline $\begin{array}{l}\text { Serum T4 concentration } \\
\text { (nmol/l) }\end{array}$ & -0.117 & 0.189 & $0.229^{* * *}$ & 0.086 & $-0.242^{* *}$ \\
\hline $\begin{array}{l}\text { Serum FT4 concentration } \\
\text { (pmol/l) }\end{array}$ & $-0.178^{\star}$ & 0.026 & -0.018 & -0.041 & $-0.266^{* *}$ \\
\hline $\begin{array}{l}\text { Serum T3 concentration } \\
\text { (nmol/l) }\end{array}$ & -0.030 & 0.044 & -0.027 & 0.010 & -0.113 \\
\hline $\begin{array}{l}\text { Serum TSH concentration } \\
(\mathrm{mU} / \mathrm{I})\end{array}$ & 0.106 & -0.058 & -0.039 & -0.066 & 0.051 \\
\hline
\end{tabular}

${ }^{\star} P=0.018,{ }^{*} P=0.001, * * P=0.002$

None of the thyroid measures showed a statistically significant correlation with the $\mathrm{PbB}$ concentration. Similar calculations were made for the thyroid indices and the EPP concentration with generally similar negative outcomes, although a weak, statistically significant positive correlation was found between the serum T4 concentration and the EPP concentration $(r=0.229, P=0.002)$.

The effect of the duration of lead exposure was investigated separately. The scatter plot in figure 2 shows the serum FT4 level as a function of the duration of lead exposure. The weak negative relationships between the FT4 concentration and the duration of exposure $(\mathrm{N}=172, \mathrm{r}=-0.266)$ and the $\mathrm{T} 4$ concentration and the duration of exposure $(\mathrm{N}=172, \mathrm{r}=-0.242)$ were statistically significant (table 3 ). Age also showed a weak negative correlation with the FT4 $(r=-0.178$, $\mathrm{P}=0.02)$ and $\mathrm{T} 4(\mathrm{r}=-0.117)$ levels.

Table 4 shows the means of the thyroid function measures stratified by length and intensity of lead exposure. In the group of workers exposed for more than 10 years the serum concentrations of T4 and FT4 were significantly lower in the workers with an individual average $\mathrm{PbB}$ level over the mean $(\mathrm{P}=0.011$ and $\mathrm{P}<0.001$, respectively).

When the analysis was restricted to the group with individual average $\mathrm{PbB}$ levels over the mean (figure 3 ), a statistically significant negative relationship was found between the FT4 level and the duration of exposure $(N=76, r=-0.577, P<0.001)$. Similar relationships existed also between the duration of lead exposure and the serum concentrations of $\mathrm{T} 4 \mathrm{~N}=76$, $\mathrm{r}=-0.459, \mathrm{P}<0.001)$ and $\mathrm{T} 3(\mathrm{~N}=76, \mathrm{r}=-0.272$, $\mathrm{P}=0.02$ ) when only workers with an individual average $\mathrm{PbB}$ level above the group mean were considered.

Variations in the serum T4 and serum FT4 levels were studied with multiple regression methods with age, the $\mathrm{PbB}$ level, the individual average $\mathrm{PbB}$ level, and the duration of lead exposure as covariates.

In the regression analyses of the whole study group the duration of exposure showed weak but significant negative associations with the T4 and FT4 levels. Regression models which included only the duration of exposure as a variable yielded the following equa- 


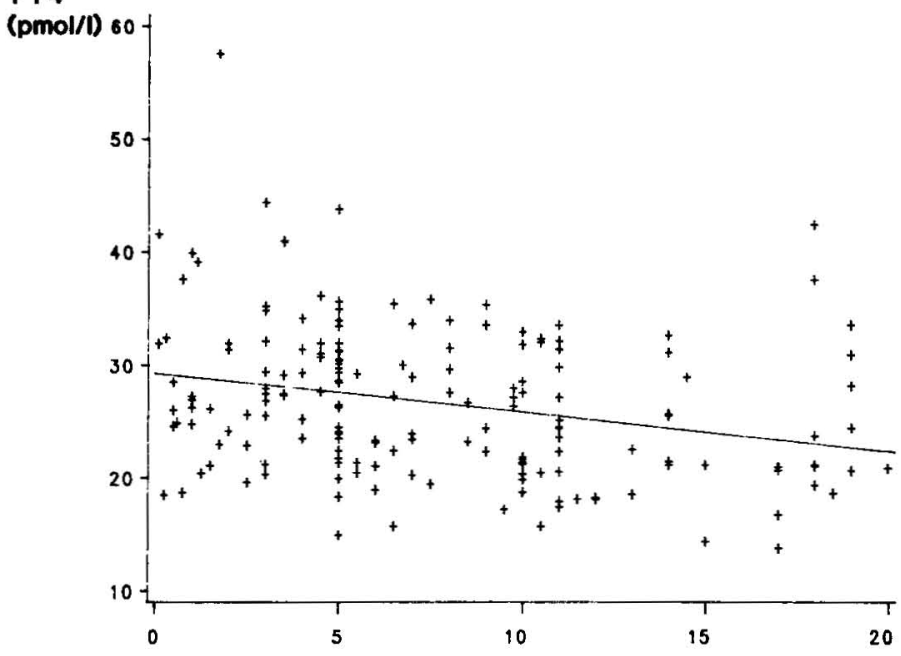

Duration of exposur
Figure 2. Relationship between the free thyroxine (FT4) in serum and the duration of lead exposure $(N=176, r=-0.266, P<0.001)$

Table 4. Means and standard deviations of the measures of thyroid function stratified by intensity and length of lead exposure. $(\mathrm{PbB}=$ blood lead, $\mathrm{T} 4=$ total thyroxine, $\mathrm{FT} 4=$ free thyroxine, T3 =trilodothyronine, $\mathrm{TSH}=$ thyroid-stimulating hormone, ie, thyrotropin)

\begin{tabular}{|c|c|c|c|c|c|c|c|c|}
\hline \multirow[t]{2}{*}{$\begin{array}{l}\text { Measure } \\
\text { of } \\
\text { thyroid } \\
\text { function }\end{array}$} & \multicolumn{2}{|c|}{$\begin{array}{c}\text { Individual average } \\
\mathrm{PbB} \leq 2.73 \mu \mathrm{mol} / 1 \\
\text { and duration } \\
\leq 10 \text { years } \\
(\mathrm{N}=74)\end{array}$} & \multicolumn{2}{|c|}{$\begin{array}{l}\text { Individual average } \\
\mathrm{PbB}>2.73 \mu \text { mol/I } \\
\text { and duration } \\
\leq 10 \text { years } \\
(\mathrm{N}=53)\end{array}$} & \multicolumn{2}{|c|}{$\begin{array}{c}\text { Individual average } \\
\mathrm{PbB} \leq 2.73 \mu \text { mol/l } \\
\text { and duration } \\
>10 \text { years } \\
(\mathrm{N}=25)\end{array}$} & \multicolumn{2}{|c|}{$\begin{array}{l}\text { Individual average } \\
\mathrm{PbB}>2.73 \mu \mathrm{mol} / \mathrm{I} \\
\text { and duration } \\
>10 \text { years } \\
(\mathrm{N}=23)\end{array}$} \\
\hline & Mean & $\mathrm{SD}$ & Mean & $S D$ & Mean & SD & Mean & SD \\
\hline $\begin{array}{l}\text { Serum T4 concentration } \\
(\mathrm{nmol} / \mathrm{l})\end{array}$ & 100.2 & 21.1 & 105.4 & 15.4 & 95.3 & 17.0 & 91.1 & $17.7^{*}$ \\
\hline $\begin{array}{l}\text { Serum FT4 concentration } \\
(\mathrm{pmol} / \mathrm{l})\end{array}$ & 27.3 & 7.5 & 27.8 & 5.0 & 26.7 & 7.1 & 21.4 & $4.0^{* *}$ \\
\hline $\begin{array}{l}\text { Serum T3 concentration } \\
\text { (nmo:/l) }\end{array}$ & 1.9 & 0.5 & 1.9 & 0.4 & 1.9 & 0.3 & 1.7 & 0.3 \\
\hline $\begin{array}{l}\text { Serum TSH concentration } \\
\text { (mU/l) }\end{array}$ & 2.5 & 1.6 & 2.6 & 1.8 & 3.2 & 1.8 & 2.7 & 1.8 \\
\hline
\end{tabular}

* $P=0.011,{ }^{* *} P<0.001$.

\section{FT 4}

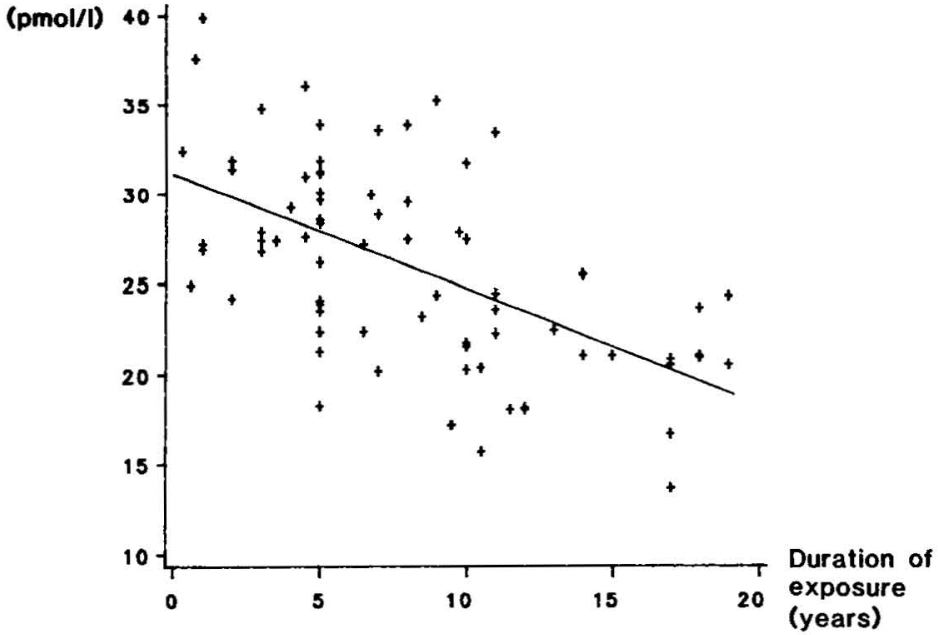

Figure 3. Free thyroxine (FT4) in serum as a function of the duration of lead exposure in the group of workers with an individual average blood lead level over the group mean $(\mathrm{N}=76, \mathrm{r}=-0.577, \mathrm{P}<0.001)$. 
Table 5. Correlations between age, the duration of exposure, the blood lead $(\mathrm{PbB})$ concentration, the individual average $\mathrm{PbB}$ concentration, and the erythrocyte protoporphyrin (EPP) concentration.

\begin{tabular}{lccccc}
\hline & $\begin{array}{c}\text { Age } \\
\text { (years) }\end{array}$ & $\begin{array}{c}\text { Duration } \\
\text { of exposure } \\
\text { (years) }\end{array}$ & $\begin{array}{c}\text { PbB } \\
\text { concentration } \\
(\mu \mathrm{mol} / \mathrm{l})\end{array}$ & $\begin{array}{c}\text { Individual } \\
\text { average PbB } \\
\text { concentration } \\
(\mu \mathrm{mol} / \mathrm{l})\end{array}$ & $\begin{array}{c}\mathrm{EPP} \\
\text { concentration } \\
(\mu \mathrm{mol} / \mathrm{l})\end{array}$ \\
\cline { 2 - 6 } Age (years) & 1.000 & $0.623^{*}$ & -0.204 & -0.140 & -0.167 \\
Duration of exposure (years) & & 1.000 & -0.021 & 0.066 & 0.020 \\
PbB concentration ( $\mu \mathrm{mol} / \mathrm{l})$ & & & 1.000 & $0.922^{*}$ & $0.748^{*}$ \\
Individual average PbB & & & & 1.000 & $0.634^{*}$ \\
concentration $(\mu \mathrm{mol} / \mathrm{l})$ & & & & 1.000 \\
EPP concentration $(\mu \mathrm{mol} / \mathrm{l})$ & & & & & \\
\hline
\end{tabular}

${ }^{\star} \mathrm{P}<0.001$.

tions (standard errors of coefficients in parentheses):

$$
\begin{gathered}
\mathrm{T} 4=105.7-0.90 \times(\text { duration of exposure }) \\
(2.6)(0.28) \\
\left(\mathrm{N}=172, \mathrm{R}^{2}=0.059, \mathrm{P}=0.002\right)
\end{gathered}
$$

and

FT4 $=29.4-0.37 \times$ (duration of exposure)

$$
\text { (0.9) }(0.10)
$$

$\left(\mathrm{N}=172, \mathrm{R}^{2}=0.071, \mathrm{P}<0.001\right)$

Insertion of the current $\mathrm{PbB}$ level, the EPP level, or age into the equation did not improve the model. When both duration of exposure and age were inserted as explanatory variables into the regression models, they explained $6.2 \%\left(\mathrm{R}^{2}=0.062\right)$ of the variability in the T4 levels and $7.2 \%\left(\mathrm{R}^{2}=0.072\right)$ of the variability in the FT4 levels. The partial correlation between the $\mathrm{T} 4$ concentration and age adjusted for the duration of exposure was 0.061 , and that between the $\mathrm{T} 4$ concentration and the duration of exposure adjusted for age was -0.228 . The partial correlation between the FT4 concentration and age adjusted for the duration of exposure was -0.028 , and between FT4 and the duration of exposure adjusted for age it was -0.195 .

Use of the individual average $\mathrm{PbB}$ level as the sole explanatory variable in the model indicated no relationship (T4: $\mathrm{N}=172, \mathrm{R}^{2}=0.007, \mathrm{P}=0.31$ and FT4: $\mathrm{N}=172, \mathrm{R}^{2}=0.002, \mathrm{P}=0.58$ ).

The effect of lead on the FT4 and T4 concentrations seemed to be the most pronounced in the group of workers with the longest and most intense lead exposure (table 4). Restriction of the regression analyses to the group of workers with an individual average exposure over the group mean showed a rather strong association between the duration of exposure and the T4 $\left(\mathrm{N}=75, \mathrm{R}^{2}=0.21, \mathrm{P}<0.001\right)$ and FT4 $(\mathrm{N}=75$, $\left.\mathrm{R}^{2}=0.33, \mathrm{P}<0.001\right)$ concentrations. In this group the $\mathrm{T} 3$ level also showed a weak negative association with the duration of exposure $\left(\mathrm{N}=75, \mathrm{R}^{2}=0.07, \mathrm{P}=0.02\right)$.

As for the TSH level, the regression analyses did not reveal a statistically significant correlation between the hormone concentration and the $\mathrm{PbB}$ level, the individual average $\mathrm{PbB}$ level, the EPP level, or the duration of exposure.
The correlations between age and the duration of exposure $(\mathrm{r}=0.623)$, the $\mathrm{PbB}$ and individual average $\mathrm{PbB}$ levels $(\mathrm{r}=0.922)$, as well as the EPP and PbB concentrations $(r=0.748)$, and EPP and individual average $\mathrm{PbB}$ levels $(\mathrm{r}=0.634)$ were statistically significant $(\mathrm{P}<0.001)$. The duration of exposure was not statistically significantly associated with the $\mathrm{PbB}$ level or the individual average $\mathrm{PbB}$ level (table 5).

The standard collinearity diagnostics for age and the duration of exposure showed only moderate values $\left(r^{2}=0.4\right.$, condition number based on the correlation matrix $k=4.3$, variance inflation factor $=1.6$ ).

\section{Discussion}

The main observation of this study was that the duration of lead exposure correlated negatively with the serum levels of FT4 and T4. This correlation was rather strong in the group of workers with the highest exposure intensity over time. In our study the current $\mathrm{PbB}$ level as a point estimate of exposure was not associated with the T4, FT4, T3, or TSH concentrations in serum. This result varies with that of Robins et al (11), who found a significant negative correlation between the estimated FT4 index (calculated from T4 and the thyroxine binding capacity) and current $\mathrm{PbB}$ levels in a subgroup of workers of African origin. Refowitz (10) did not find a significant association between the FT4 index (T4 $\times$ T3 resin uptake) and the current $\mathrm{PbB}$ concentration.

We observed a statistically significant negative correlation between the serum concentration of FT4 and the duration of exposure, particularly in the group of workers with the highest exposure intensity over time. Thus our findings support the view that long-term, intense exposure to lead might be associated with depressed thyroid function.

The observation that the duration of lead exposure at work was negatively correlated with the FT4 and $\mathrm{T} 4$ concentrations has not been previously reported. Duration of exposure and age were correlated covariates. Therefore, age must be considered as a potential confounding factor. There are reports $(5,17)$ show- 
ing a decrease in T4 and T3 levels and their corresponding free hormone indices in a group of aging men (30-96 years). On the other hand, most studies have not revealed any significant decrease in serum T4 with age $(6,8,13)$. Controlling for age in the multiple regression analyses did not affect the relationship between duration of lead exposure and FT4 or T4 level in the present study. Furthermore, all the workers were relatively young (under 55 years of age). Statistical analyses indicated that collinearity between age and duration of exposure cannot be expected to be a problem with respect to the present data.

Therefore it is possible that intense and long-term lead exposure may in time depress thyroid function through some mechanism(s). The possible mechanism(s) of the long-term lead exposure effect would be (i) a direct effect of lead on the thyroid, the result being a primary depression in thyroid gland function; (ii) an effect on the hypothalamopituitary level, the result being secondary thyroid effect; or (iii) an effect on the peripheral turnover of thyroid hormones.

If the mechanism were mild subclinical primary hypothyroidism, one would expect a reciprocal rise in the TSH levels. Such a correlation between the T4 or FT4 and TSH concentrations was not observed, not even in the group exposed long-term.

Neither do we have any positive evidence for an effect through the hypothalamopituitary axis. On the other hand, we cannot rule out such a mechanism as, unfortunately, the TSH concentrations were determined by a method with a detection limit of $0.8 \mathrm{mU} / \mathrm{l}$. Thus low TSH values which would fit this mechanism could not be detected.

The possibility of a peripheral effect by lead exposure such as the so-called sick euthyroid syndrome, as suggested earlier $(2,15)$, does not seem plausible because a greater lowering effect would then be expected for the T3 level than for the T4 and FT 4 levels. Furthermore, the study group consisted of healthy workers, not of sick patients.

In summary, contrary to some earlier reports, the current $\mathrm{PbB}$ (or EPP) level was not associated with the results of routine laboratory tests of thyroid function. However, a weak but statistically significant negative association was observed between the duration of exposure to lead and the T4 and FT4 concentrations. The association was particularly pronounced when the analysis was restricted to workers with the highest exposure intensity over time. This observation suggests that thyroid function might suffer as a result of intense long-term lead exposure.

\section{References}

1. Afifi AA, Azen SP. Statistical analysis: A computer oriented approach. Second edition. Academic Press, New York, NY 1979.

2. Beidleman B. Editorial comment. J Occup Med 26 (1984) $582-583$.

3. Cullen MR, Kayne RD, Robins JM. Endocrine and reproductive dysfunction in men associated with inorganic lead intoxication. Arch Environ Health 39 (1984) $431-440$.

4. Environmental Sciences Associates Inc. ZnP hematofluorometer model 4000, manual. Burlington, MA 1975.

5. Harman SM, Wehmann RE, Blackman MR. Pituitarythyroid hormone economy in healthy aging men: Basal indices of thyroid function and thyrotropin responses to constant infusion of thyrotropin releasing hormone. J Clin Endocrinol Metab 58 (1984) 320-326.

6. Herman J, Rusche HJ, Hilger TP, Kruskemper HL. Free triiodothyronine (T3) and thyroxine (T4) serum levels in old age. Horm Metab Res 6 (1974) 239-244.

7. Kremer HU, Frank MN. Coexisting myxederna and chronic plumbism. Ann Intern Med 42 (1955) 11301136.

8. Lipson A, Nickoloff EL, Hau TH, Kasecamp WR, Drew HM, Shakir R, Wagner HN. A study of age-dependent changes in thyroid hormone tests in adults. J Nucl Med 20 (1979) $1124-1127$.

9. Porritt N. Cumulative effects of infinitesimal doses of lead. Br Med J 2 (1931) 92-94.

10. Refowitz RM. Thyroid function and lead: No clear relationship. J Occup Med 26 (1984) 579-582.

11. Robins JM, Cullen MR, Connors BB, Kayne RD. Depressed thyroid indexes associated with occupational exposure to inorganic lead. Arch Intern Med 143 (1983) 220-224.

12. Sandstead HH, Stant EG, Brill AB, Arias LI, Terry RT. Lead intoxication and the thyroid. Arch Intern Med 123 (1969) 632-635.

13. Sawin CT, Chopra D, Azizi F, Mannix JE, Bacharach P. The aging thyroid: Increased prevalence of elevated serum thyrotropin levels in the elderly. J Am Med Assoc 242 (1979) 247-250.

14. Subramanian KS, Meranger J-C. A rapid electrothermal atomic absorption spectrophotometric method for the cadmium and lead in human whole blood. Clin Chem 27 (1981): 11, 1866-1871.

15. Tiwari I, Timms P, Rothe P. Lead poisoning and euthyroid hyperthyroxinaemia. Lancet 1 (1985) 1508-1509.

16. Weisberg S. Applied linear regression. Second edition. John Wiley \& Sons, New York, NY 1985.

17. Wenzel KW, Meinhold H, Adlkofer F, Scheusener H. TRH-Stimulationtest mit alters- und geschlechtsabhangingen TSH Anstieg bei Normalpersonen. Klin Wochenschr 52 (1974) 721-723.

Received for publication: 29 January 1988 